\title{
Heterotopic triplet gestation in natural conception following an IVF cycle: a rare case report
}

\author{
Akshaya Mahapatro*, Kundavi Shankar, Thankam Varma
}

Institute of Reproductive Medicine, Madras Medical Mission, Chennai, India

Received: 04 December 2015

Revised: 17 January 2016

Accepted: 23 January 2016

\section{*Correspondence:}

Dr Akshaya Mahapatro,

E-mail: dr.aks73 @ gmail.com

Copyright: (C) the author(s), publisher and licensee Medip Academy. This is an open-access article distributed under the terms of the Creative Commons Attribution Non-Commercial License, which permits unrestricted non-commercial use, distribution, and reproduction in any medium, provided the original work is properly cited.

\begin{abstract}
Heterotopic gestation although common with assisted conception techniques is very rare with natural conception. High index of suspicion is required for timely intervention and prevention of morbidity and mortality. We report a rare case of heterotopic pregnancy in a 34 year of G2 P1 L2 women with previous conception following ART (IVF) for unexplained infertility. She presented with $7 \frac{1 / 2}{2}$ weeks of amenorrhoea with no other signs or symptoms and diagnosis picked up on ultrasound examination as triplet gestation at 7 weeks with twin intrauterine gestation with sac $1-19 \times 5 \mathrm{~mm}$ with intrauterine live fetus, sac $2-17 \times 7 \mathrm{~mm}$ gestational sac, no yolk sac or fetal pole imaged anembryonic intrauterine pregnancy and sac -3 as right adnexal sac $5 \times 6 \mathrm{~mm}-$ anembryonic right ectopic pregnancy. She was managed successfully with suction $\&$ evacuation $\&$ methotrexate.
\end{abstract}

Keywords: Anembryonic, Ectopic, Gestational sac, Methotrexate

\section{INTRODUCTION}

Intrauterine pregnancy associated with ectopic pregnancy called as Heterotopic pregnancy. Diagnosis of heterotopic pregnancy needs high level of suspicious detection of intrauterine pregnancy may be over looked for ectopic location. Prevalence is more with ART \& ovulation induction. It is infrequent in Natural conception cycles occurring in 1:30000 pregnancy ${ }^{1,2}$.

\section{CASE REPORT}

A 34 years G2 P1 L2 presented with $7 \frac{1}{2}$ weeks of amenorrhoea with UPT positive, clinically asymptomatic. Ultrasound examination was done showing triplet gestational sac at 7 weeks with sac $1-19 \times 5 \mathrm{~mm}$ with intrauterine live fetus, sac $2-17 \times 7 \mathrm{~mm}$ gestational sac, no yolk sac or fetal pole imaged - Anembryonic intrauterine pregnancy and sac 3 - as right adnexal sac 5 $\times 6 \mathrm{~mm}$ - Anembryonic right ectopic pregnancy (Figures 1 $\& 2$ ). Patient was counselled and opted for termination of pregnancy in view of previous deliveries of twins one year back. She underwent suction evacuation and medical management of ectopic gestation with inj. Methotrexate (single dose). She was followed with $\beta$ hCG. On day of evacuation $\beta \mathrm{hCG}$ was 31,000 units and 4 days post Methotraxate was 1780 units and came down to 225 units on day 7 and Negative within 2 weeks of time.

\section{DISCUSSION}

Heterotopic ectopic pregnancy is difficult to diagnose clinically. Typically, operative procedure in form of laparotomy or laparoscopy is performed because of complications of adnexal pregnancy like tubal rupture. The incidence was originally estimated on theoretical basis 1 in 30, 000 pregnancies. ${ }^{1,2}$ However, more recent data indicate that the incidence is higher due to rise in assisted conception and was estimated to be 1 in 7000 over all \& 1 in 700 following assisted conception. ${ }^{3,4}$ Heterotopic triplets in a natural cycle, with a tubal ectopic 
and coexisting twin intrauterine gestations, are very rare. $^{5,6}$

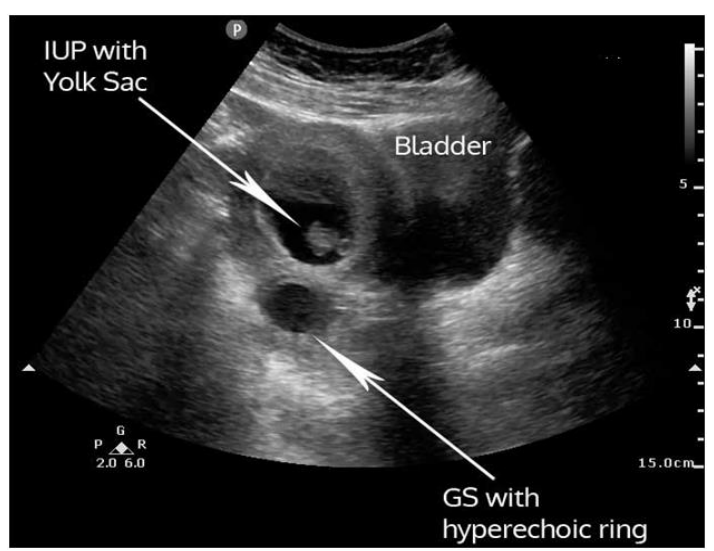

Figure 1: Showing intrauterine gestation with right adnexal gestational sac.

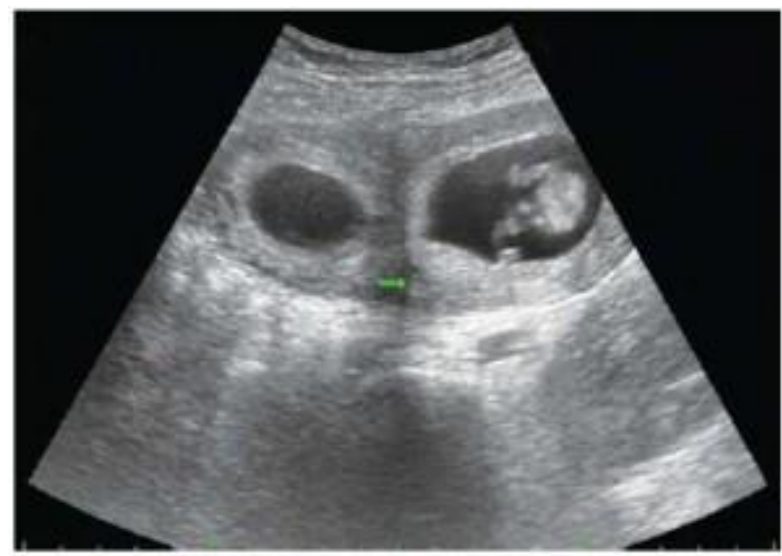

Figure 2: Showing twin pregnancy with one anembryonic gestational sac.

The increase incidence of ectopic and multiple pregnancies following assisted conception increase the chance of heterotophic pregnancy as well. The hydrostatic pressure generated during the embryo transfer may also contribute to increased risk. ${ }^{3}$ There may be increased risk in patients with previous tubal surgeries. ${ }^{7}$ Heterotrophic pregnancies may have various clinical presentations. Higher suspicion should be there following assisted conception, persistent or rising levels of human chorionic gonadotrophins following dilatation and curettage for induced or spontaneous abortion, more than one corpus luteum in natural conception, absence of vaginal bleeding with signs and symptoms of ectopic gestation. ${ }^{8}$ Heterotopic gestation can also present as haematometra and lower abdominal pain in early gestation or may rarely be asymptomatic. ${ }^{9-11}$ Majority of reported heterotopic pregnancies are singleton intrauterine pregnancies. Triplet and quadruplet heterotropic pregnancies have also been reported though the incidence is very rare. ${ }^{11-13}$ Majority of reported cases are of singleton intrauterine conception and it is more frequent following assisted conception. ${ }^{8}$ Intrauterine gestation with hemorrhagic corpus luteal cyst, bicornuate uterus with gestation in both cavities including other surgical conditions of acute abdomen can simulate heterotopic gestation clinically and hence the difficult diagnosis. ${ }^{14}$ High resolution transvaginal ultrasound with colour Doppler will be helpful as the trophoblastic tissue in the adnexae in case of heterotopic pregnancy shows increased flow with significantly reduced resistance index. ${ }^{4}$ Active intervention is mandatory in case of heterotopic pregnancy with attempt to save the intrauterine gestation can be made if desired. ${ }^{15}$ The illustrated case did not have any clinical signs and was picked on ultrasound, since the patient was not willing to continue the pregnancy so suction evacuation of intrauterine products with medical management of ectopic pregnancy was done. Heterotopic pregnancy though very rare following natural conception can be picked up early if there is high index of suspicion. Early and timely diagnosis and management can help lower down the morbidity and mortality as well.

\section{Funding: No funding sources \\ Conflict of interest: None declared \\ Ethical approval: Not required}

\section{REFERENCES}

1. Talbot K, Simpson R, Price N, Jackson SR. Heterotopic pregnancy. J Obstet Gynaecol. 2011;31:7-12.

2. Varras M, Akrivis C, Hadjopoulos G, Antoniou N. Heterotopic pregnancy in a natural conception cycle presenting with tubal rupture: a case report and review of the literature. Eur J Obstet Gynaecol Reprod Biol. 2003;106:79-82.

3. Lyons EA, Levis CS, Sidney M. Dashefsky in diagnostic ultrasound. In: Rumak CM, Wilson SR, Charboneau WK, Mosby. 1998;2,2:999.

4. Glassner MJ, Aron E Eskin BA. Ovulation induction with clomiphene and rise in Heterotropic pregnancies: A report of two cases. J Reprod Med. 1990;35:175-8.

5. Ludwig M, Kaisi M, Bauer O, Diedrich K. Heterotopic pregnancy in a spontaneous cycle: do not forget about it. Eur J Obstet Gynecol Reprod Biol. 1999;87:91-103.

6. Jerrard D, Tso E, Salik R, Barish RA. Unsuspected heterotopic pregnancy in a woman without risk factors. Am J Emerg Med. 1992;10:58-60.

7. GruberI, Lahodny J, Illmenesee K, Losch A. Heterotropic pregnancy: report of three cases. Wein Klin Wochenschr. 2002;144:229-32.

8. Multifoetal ectopic pregnancy, ectopic pregnancy, text book of Williams obstetrics. 21:889-0.

9. Cheng PJ, Cheuh HY, Qiu JT. Heterotropic pregnancy in natural conception cycle presenting as hematometra. Obstet gynecol. 2004;104:195-8.

10. Govindrajan MJ, Rajan R. Heterotropic pregnancy in natural conception. J Hum Reprod Sci. 2008;1:37-8. 
11. Peleg D, Bar Hava I, Neamen Leavin M, Ashkena, Ben- rafaelz IJ. Early diagnostic and successful non surgical treatment of viable combined intrauterine and cervical pregnancy. Fertil Steril. 1994;62:405.

12. Alsunaidi MI, an unexpected spontaneous triplet pregnancy. Saudi Med J. 2005;26:136-8.

13. Sherer DM, Scibetta JJ, Sanko SR. Heterotropic quadruplet gestation with laparoscopic resection of ruptured interstitial pregnancy and subsequent successful outcome of triplets. Am J Obstet gynaceol. 1995;172:216.
14. Sohail S. Hemorrhagic corpus luteum mimicking Heterotropic pregnancy. J Coll Physicians Surg Pak. 2005; 15:180-1.

15. Espiona PM, Alcantar Mendoza MA. Heterotropic pregnancy: report of a case and review of literature. Gynecol Obstet Mex. 1997;65:482-6.

Cite this article as: Mahapatro A, Shankar K, Varma T. Heterotopic triplet gestation in natural conception following an IVF cycle: a rare case report. Int J Reprod Contracept Obstet Gynecol 2016;5:576-8. 